\title{
Hershey Arena: Anton Tedesko's Pioneering Form
}

\author{
Edmond P. Saliklis, M.ASCE, ${ }^{1}$ and David P. Billington, Hon.M.ASCE ${ }^{2}$
}

\begin{abstract}
Civil engineering structures are part of our cultural heritage. The story of who we are can be told, in part, by what we have built. There have been pivotal moments in civil engineering design history wherein a master engineer creates a pioneering structure. One major example is Anton Tedesko's 1936 Hershey Ice Arena, the first large-scale thin shell concrete roof in the United States. Tedesko left all his papers, including the original design and analysis calculations of the Hershey shell, to the Princeton Maillart Archives. These documents, as well as other archival materials and photographs, provide insight into the design history of Hershey, and the transfer of thin shell technology to America. In this paper, we retrace the design and analysis calculations performed by Tedesko, and compare them to modern computer models. We show that the hand calculations are sufficiently accurate, and in fact are necessary for initial form finding. We close by pointing out the enormous impact that this design had in thin shell concrete construction, and argue for the preservation of this remarkable structure.
\end{abstract}

CE Database keywords: Thin shell structures; Technology transfer; Conceptual design; Historic sites; Roofs; Structural engineering.

\section{Introduction}

This paper seeks to establish the major significances of the 1936 Hershey Ice Arena, to illustrate through this building several crucial and timeless ideas about structural engineering, and to describe and critique the design and construction of the major thin shell concrete roof structure.

The major significance lies in its pioneering form, its distinguished designer, its excellent condition two-thirds of a century after completion, and its matchless qualifications as a national historic landmark. This arena was the first large-scale barrel shell roof in the United States, establishing a precedent for a series of such structures over the next two decades. Anton Tedesko (19031994) designed the shell, took personal and full charge of its construction, and because of its success became the leading thin shell engineer in the United States. He subsequently received practically every major award available to a structural engineer. His arena was so well designed and built that it remains in exceptionally sound condition at the start of the 21 st century; and it still exhibits all the features that Tedesko designed including its stunning image inside and its powerful impression from the outside. All of these factors make the Hershey Arena a prime candidate for designation as a national historic landmark and for landmark designation by the American Society of Civil Engineers.

This building characterizes the crucial and timeless ideas for structural engineering of technology transfer, of conceptual de-

\footnotetext{
${ }^{1}$ Assistant Professor, Dept. of Civil and Environmental Engineering, Acopian Engineering Center, Lafayette College, Easton, PA 18042-1775. E-mail: saliklie@lafayette.edu

${ }^{2}$ Gordon Y.S. Wu Professor of Engineering, Dept. of Civil and Environmental Engineering, Princeton Univ., Princeton, NJ.
}

sign, and of the intimate connection between design and construction. Tedesko single-handedly brought that technology of thin shell concrete roof structures to the United States from its country of origin, Germany. He took ideas developed in one society, transferred them to another society, and changed those ideas to fit that destination, the United States. The Hershey Arena represents the first and formative stage in that transformation where he had to explain this radically new form to American engineers and then prove to them that it could be built economically in a new social context. A major part of this explanation involved demonstrating a conceptual design that would be both reasonably accurate and convincingly clear to those unfamiliar with the foreign experience. By building his conceptual calculations around the standard arch form, Tedesko could show how his huge structure could easily carry the design loads. But he also had to convince engineers and especially his client the Hershey organization that his plans for construction would be structurally sound and economically satisfactory. Any concrete structure is weakest during the construction and therefore the process of building is as critical as the performance after completion. Thus, Tedesko had to think about construction as he thought about design. His German experience was with the pioneering firm of Dyckerhoff and Widmann A.G., which did both design and construction. Thus, as a builder Tedesko was intimately familiar with all aspects of the design.

Finally, we critique the design and construction to show the conservative basis for Tedesko's calculations, the elementary features of his design, and the difficulties he faced in directing an almost totally inexperienced construction crew. Without his contagious confidence the project would never have been carried through to a successful end.

\section{Background}

The Hershey Ice Arena was designed and constructed at a time when the United States was in the midst of a great depression (Hershey 1989). Many prominent sites at Hershey, Pennsylvania were constructed during this time (Community Building, Hotel Hershey, the Windowless Office Building). M.S. Hershey said 
(Hershey 1954) to fellow managers over lunch, "Gentlemen, we are told we are having a depression in this country and unemployment. I have brought about six hundred workmen to this town, engaged in building operation... Therefore, I have made up my mind that, since building materials are now at the lowest-cost level, I am going to build a community building, a hotel, a school, and so take care of my people." For us to admit there was an element of shrewdness in Mr. Hershey's philanthropies, is no belittlement of his motives nor of his contribution to society through the example of his model town. The Depression provided Hershey with a sizeable labor force of workers to carry out his large-scale building plans. He was able to build at the lowest-possible cost while helping the local economy by maintaining full employment (Cassidy and Harrison 1988). On the other hand, construction photos of this project show a large number of automobiles parked adjacent to the site, indicating that Mr. Herhsey must have paid a wage commensurate with skilled labor. People in Hershey today still reflect on that era with a sincere pride that there was no depression in their planned community (Hershey 1989).

One man, Mr. Paul Witmer, began to assume more and more responsibility of the construction management of these projects. Originally a house builder in the late 1920s for Hershey's planned community, Witmer had progressed by 1930 to manager of the Hershey Convention Hall which then served as the original ice arena for the newly formed amateur hockey team, the Hershey Bears. In 1934, the Bears won the league championship, and became so popular that many times only standing room was available in the Convention Hall arena (Snavely, unpublished, 1957). So Mr. Hershey had Paul Witmer solicit plans for a new, larger building.

In another part of the world, in 1926, Anton Tedesko, graduated from the Technological Institute of Vienna with a diploma in Civil Engineering. Tedesko studied bridge design from academic engineers such as Friederich Hartmann, Josef Melan, and Rudolf Saliger. His education and practice in Europe emphasized the combination of design and construction within the same company. Such engineering firms stressed competitive designs much more than in the United States. Tedesko worked for one year with a contractor on a large Vienna city housing project gaining field supervision experience. He also traveled to the United States, arriving in 1927, where he worked with a fellow Austrian engineer, Hans (later John) Kalinka, as a draftsman and detailer while developing his facility in English.

Upon his return to Europe in May of 1929, Tedesko was hired by one of his former professors, Ernst Melan, who subsequently urged Tedesko to work toward a doctor's degree which would lead to an academic career (Billington 19982a). After six months however, Tedesko chose practice over research and went to work with the well-known design build firm, Dyckerhoff and Widmann in Weisbaden. Dyckerhoff and Widmann had experience in the design and construction of planetarium domes and of barrel and dome-shaped market halls. Here Tedesko's thin shell practice began. As he gained experience and as the firm gained confidence in his abilities, a new possibility opened up. Thanks to Tedesko's personal relationship with Kalinka, who by then was an established design engineer in the design-construction firm Roberts and Schaefer in Chicago, Dyckerhoff and Widmann decided to transfer the young Tedesko to Chicago to introduce thin shell concrete construction into the United States. In 1932, Tedesko returned to the United States. This time, his mission was to drum up new business for this newly patented thin shell concrete construction method. Tedesko worked incessantly through the mid 1930 s with many unrealized proposals. He ran into resistance from conservative steel designers, and the harsh economic climate of a deep recession. Up to 1932 there had been almost nothing written in the United States on concrete thin shells. Tedesko wrote an article on the design of thin shelled concrete structures which was published anonymously in 1932 (Billington 1982b).

By 1935, Tedesko had professional friends and contacts including the Portland Cement Association representative James Gibson in Philadelphia. Gibson acted as an intermediary to the Hershey Corporation who were in need of a new ice arena at this time. The 32 year old Tedesko leapt at the chance to design the largest monolithic concrete roof structure in North America. There was no American precedent for such a structure, no design codes, no established construction practices for a project of this scale requiring such careful tolerances. On January 21, 1936, Tedesko, helped by Gibson, presented his idea for a huge stadium to Paul Witmer, who in turn presented it to Mr. Hershey. "I was somewhat startled when Witmer showed me the plans, for I hadn't figured building such a large structure, and I had to think twice before I let him go ahead with its construction," said Milton Hershey (Snavely 1957). Tedesko hired staff in Chicago, design work started immediately, and on February 7 he began to write out in detail the full calculations for the roof structure. This manuscript, housed in the Princeton Maillart Archives, forms the basis of this paper. Tedesko completed his design and analysis by February 28 and ground was broken on March 11 to begin work.

The building is composed of a barrel vault roof, then known as the Zeiss-Dywidag type. The concrete shell is only $31 / 2$ in. thick, and is stiffened at $39 \mathrm{ft}$ intervals by two-hinged arch ribs. There are eight arch ribs that spring from 1 in. thick lead pads which act as base plates. The roof crown is $100 \mathrm{ft}$ above the floor, and the shell was constructed as five separate units, with expansion joints between each unit (Tedesko 1937a). The shell cantilevers are $19 \mathrm{ft}$ $7 \mathrm{in}$. from arch to expansion joint, where a stiffening rib has been provided. Each arch has a theoretical span of $222 \mathrm{ft}$ and a rise of $81 \mathrm{ft}$. Arches are $22 \mathrm{in}$. wide and $60 \mathrm{in}$. deep at the crown, increasing in depth toward the springing line (see Fig. 1 and Table 2). The structure is $343 \mathrm{ft}$ in length.

\section{Search for Proper Engineering Form}

The form Tedesko created was intended to "achieve both a monumental appearance and maintenance-free permanence at a reasonable cost" (Tedesko 1937a). Yet the form is not a sculptural, architectural form but rather, a rational engineering form that has met Tedesko's stated criteria. He certainly would have looked to his colleagues at Dyckerhoff and Widmann for advice and for assistance in the calculations, yet there was virtually no precedent for a structure of this scale anywhere in the world, certainly none in the United States. The thrill of exploring such previously unrealized forms is captured in the following line from a promotional brochure describing the new concrete technology: "We can now glimpse the possibility of transcending the devine (sic) art of the monks, those masters of living stone whose arches, vaults and choirs rose towards heaven in a lace-like tracery till then unknown." (Dyckerhoff and Widmann 1931). The only benchmark Tedesko had was the Storage Hall for salt at Tertre, Belgium, built in 1930. It had a span of $144 \mathrm{ft}$ and a height of $47 \mathrm{ft}$ with arch ribs spaced at $33 \mathrm{ft}$, thickness of shell is $23 / 8$ in. (Dyckerhoff and Widmann 1931).

A page from these documents (Tedesko 1936), reproduced in Fig. 1, shows how Tedesko laid out the size and the shape of the arch rib and shell roof with a few simple calculations. Let us briefly examine some of these design ideas. 


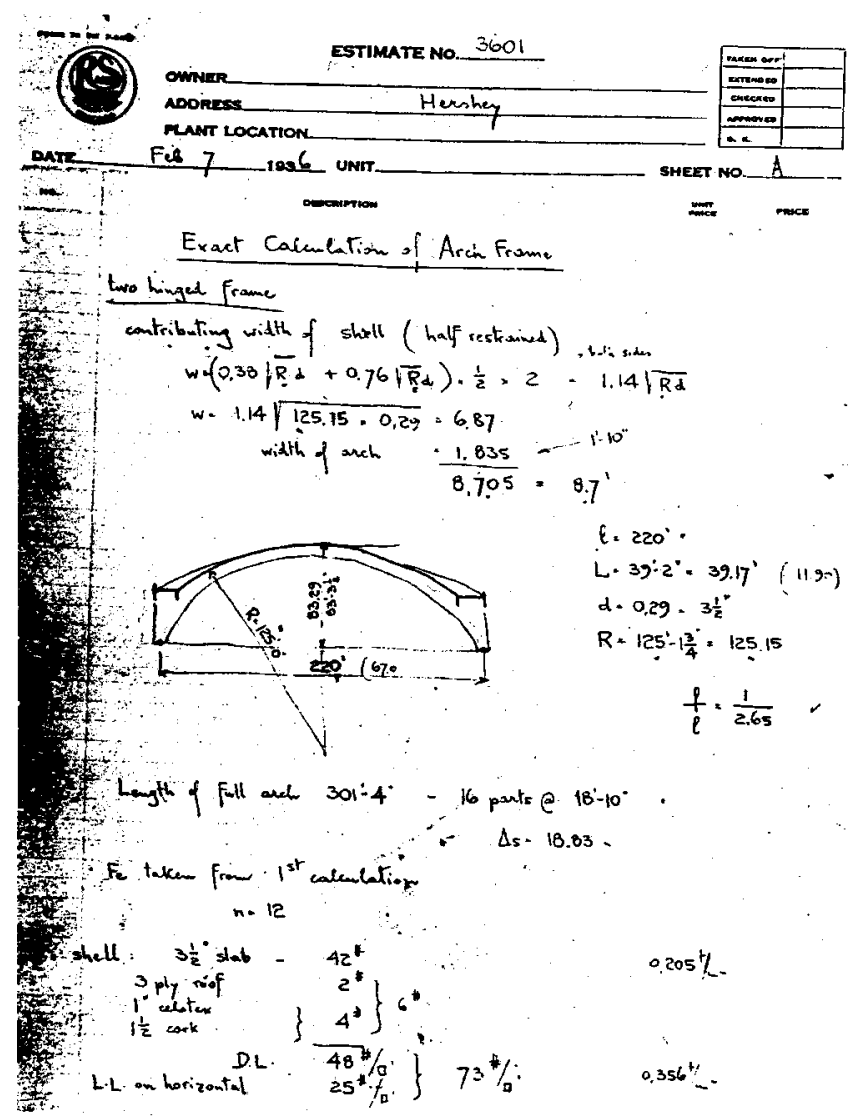

Fig. 1. Tedesko's hand calculations

The overall width of the space was dictated by the ice hockey arena size as well as seating for 7,000 people. Tedesko started out by working with a span $(L)$ of $220 \mathrm{ft}$ and chose the shell thickness of $31 / 2$ in. based on previous experience (Hayden Planetarium 1935). The major portion of the roof has a radius of curvature of $132 \mathrm{ft}$ (slightly more than is shown in the sketch of Fig. 1). Later drawings show that this radius is reduced to $42 \mathrm{ft}$ at $42^{\circ}$ from the crown of the shell. Tedesko chose to make the roof shell somewhat elliptical to increase the stiffness near the horizontal supporting boundary. The $31 / 2$ in. shell thickness is increased to 6 in. near the springing line. The rise to the shell at the crown 83.29 $\mathrm{ft}$ and $81.1 \mathrm{ft}$ to the centroid of the arch rib at the crown. A somewhat cryptic line of calculations in Fig. 1 is $\rho / \ell=1 / 2.65$. Our research led us to conclude that Tedesko felt comfortable with his initial sizing of the shell structure because it approximated the dimensions of the Salt Storage Hall in Tertre designed by the firm Dyckerhoff and Widmann. Tedesko was concerned about the role of the ratio of rise to unsupported length $(L)$ in the design.

$$
\frac{47}{144}=\frac{1}{3.06}=0.327 \text { Tertre } \frac{83.29}{220}=\frac{1}{2.65}=0.379 \text { Hershey }
$$

Tedesko summarizes the distributed roof dead load as $48 \mathrm{lb} / \mathrm{ft}^{2}$ and roof live load as $25 \mathrm{lb} / \mathrm{ft}^{2}$. Using the dead load plus live load value of $73 \mathrm{lb} / \mathrm{ft}^{2}$ shown at the bottom of Fig. 1, a membrane stress analysis shows the following very small stress:

$$
\sigma_{\mathrm{DL}+\mathrm{LL}}=\frac{p \times r}{t}=\frac{73 \times 132 \times 12}{3.5}=33,943 \mathrm{psf}=236 \mathrm{psi}
$$

Since dead load would be of primary concern for a buckling analysis, a check of the dead load membrane stresses shows
Table 1. Horizontal Thrust: Two-Hinged Arch Versus Three-Hinged Arch

\begin{tabular}{lcc}
\hline Rib alone & Three-hinged & Two-hinged \\
& $H=137 \mathrm{k}$ & $H=133 \mathrm{k}$ \\
\hline Rib, roof, snow & Three-hinged & Two-hinged \\
& $H=404 \mathrm{k}$ & $H=352 \mathrm{k}$ \\
\hline
\end{tabular}

$$
\sigma_{\mathrm{DL}}=\frac{p \times r}{t}=\frac{48 \times 132 \times 12}{3.5}=21,723 \mathrm{psf}=151 \mathrm{psi}
$$

In an article describing the Hershey project, Tedesko refers (Tedesko 1937b) to a buckling analysis performed via the method proposed by Flügge (Flügge 1934). The details of the buckling calculations have not been published, yet we can recreate the buckling analysis by referring to the materials that Tedesko had at the time. Tedesko used Flügge's textbook (Flügge 1934) which was not yet translated into English. Flügge in turn referred to Timoshenko's Theory of Elastic stability, specifically Eqs. (11) and (12). Timoshenko cites the reference of this equation to Von Mises (1914). Certainly Flügge also had access to that formula, as he was part of this German tradition. Later, Manual 31 of the ASCE (ASCE 1952) reproduces this equation in their Fig. 36, which plots $r / l$ (radius/length between stiffening ribs) and $r / t$ (radius/shell thickness) versus $\sigma_{\mathrm{cr}} / E$ (critical buckling stress/ modulus of elasticity). For the dimensions at Hershey, $r / l$ $=125 \mathrm{ft} / 39 \mathrm{ft}=3.2$ and $r / t=125 \mathrm{ft} /(3.5 \mathrm{in} . / 12)=429$ which corresponds to $\sigma_{\mathrm{cr}} / E=330 \times 10^{-6}$ from page 99 of Manual 31. With $E=3,000,000$ psi this gives a critical buckling stress of 990 psi. However, at that time, for creep under permanent load it was common practice to use $1 / 3$ of $E$ in critical stress calculations. Thus, Tedesko would have calculated $\sigma_{\mathrm{cr}}=330 \mathrm{psi}$. Comparing this $\sigma_{\text {cr }}$ to $\sigma_{\text {DL }}$ of Eq. (3), we see that this pure unstiffened shell has a buckling factor of safety of slightly more than 2 .

For the conceptual design, Tedesko initially considered the arch ribs to be three hinged. The arch ribs were intended in the final design, to be two-hinged because the arch footings are partly on clay and partly on rock. And the final analysis he performed was indeed an indeterminate analysis of a two-hinged arch. But initially, the reduced cross section near the crown allowed Tedesko to consider them as hinged at the crown also. This is borne out by the summary in Table 1 for the case of weight of the arch rib alone, and then for the case of total dead load plus live load. Three-hinged arches are easily calculated by hand. The twohinged results are taken from Tedesko's indeterminate analysis.

During his initial sizing of the rib, Tedesko would have checked the total stress in the rib at the crown, based on the simple three-hinged assumption, which is conservative compared to the two-hinged assumption. Furthermore, he would have focused on the dead load stress because the live load stresses would not cause creep buckling. Even with the added snow loads, the axial stress at the crown is small, which highlights the conservative nature of this design

$$
\sigma=\frac{H}{A}=\frac{404 \mathrm{k}}{5 \times 12 \times 22 \text { in. }^{2}}=306 \mathrm{psi}
$$

\section{Structural Analysis: Hand Calculations and Computer Modeling}

In this section, we describe the hand calculations that Tedesko performed on the statically indeterminate arch ribs, and on the 
Table 2. Calculating Horizontal Thrust, Rib Only, Tedesko's Values

\begin{tabular}{|c|c|c|c|c|c|c|c|c|c|c|}
\hline Point & $\begin{array}{c}\text { Depth } \\
\text { (ft) }\end{array}$ & $\begin{array}{l}\text { Width } \\
\text { (ft) }\end{array}$ & $\begin{array}{c}I \\
(\mathrm{ft})\end{array}$ & $\begin{array}{l}\text { Rise } y \\
(\mathrm{ft})\end{array}$ & $K$ & $\begin{array}{c}M \\
(\mathrm{ft} \mathrm{k})\end{array}$ & $\begin{array}{c}M y K / I \\
\left.\mathrm{lb} / \mathrm{ft}^{2}\right)\end{array}$ & $\begin{array}{l}y^{2} K / I \\
\left(1 / \mathrm{ft}^{2}\right)\end{array}$ & $\begin{array}{l}\text { Segment weight } \\
\text { (k) }\end{array}$ & $\begin{array}{c}x \\
(\mathrm{ft})\end{array}$ \\
\hline 0 crown & 5 & 1.83 & 37.8 & 81.1 & 1 & 11120 & 23858 & 174 & 26.02 & 9.33 \\
\hline 1 & 5.1 & 1.83 & 37 & 79.6 & 4 & 10760 & 92594 & 685 & 27.1 & 28 \\
\hline 2 & 5.4 & 1.83 & 42.3 & 75.2 & 2 & 10216 & 36324 & 267 & 29.25 & 45.8 \\
\hline 3 & 5.9 & 1.83 & 56 & 68 & 4 & 8815 & 42816 & 330 & 32.3 & 62.5 \\
\hline 4 & 6.6 & 1.83 & 78.3 & 58.2 & 2 & 7354 & 10932 & 87 & 38.7 & 78.1 \\
\hline 5 & 8.9 & 1.83 & 150 & 46.8 & 4 & 5355 & 6683 & 58 & 60.23 & 92.8 \\
\hline 6 & 14.4 & 1.83 & 530 & 34.4 & 2 & 2806 & 364 & 4 & 93.2 & 105.8 \\
\hline 7 & 16.7 & 2.16 & 934 & 18.8 & 4 & 803 & 65 & 2 & 96.8 & 108.8 \\
\hline \multirow[t]{2}{*}{8 base } & 12 & 2.16 & 356.5 & 0 & 1 & 0 & 0 & 0 & 0 & 110.0 \\
\hline & & & & & & Summation & 213636 & 1608 & 403.6 & \\
\hline
\end{tabular}

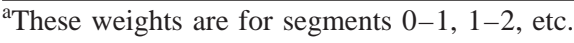

shell. The rib analyses he performed are an application of what were then the most advanced ideas in structural analysis. This included an elegant use of numerical integration. His results are sufficiently accurate for design when compared to modern computer analyses, and the design details such as typical steel reinforcement are conservative. The calculations will be described in three stages; indeterminate two-hinged arch rib, membrane analysis of the shell, and finally a superposition of shell and arch rib.

\section{Two-Hinged Arch Analysis}

Tedesko first analyzed the arch ribs as statically indeterminate subjected to tributary area loadings from the shell. The essence of Tedesko's analysis of the arch was to use the flexibility method to determine the horizontal thrust. First, he considered the arch to be pinned at one end, and roller supported at the other. The horizontal movement at the roller supported end

$$
\Delta_{10}+H \times \Delta_{11}=0
$$

where

$$
\Delta_{10}=\int \frac{M \times m}{I} d s \text { and } \Delta_{11}=\int \frac{m \times m}{I} d s .
$$

Here, $M=$ moment due to applied load on a statically determinate arch $(H=0)$ and the moment $m$ is due to a unit horizontal load acting at the supports, having a moment arm to any cut in the arch a vertical distance $y$. Thus

$$
\Delta_{11}=\int \frac{y^{2}}{I} d s
$$

The integral in the Eq. (6) was numerically evaluated using Simpson's rule, since the arch is nonprismatic, and $I$ varies with $y$. Then

$$
\int \frac{y^{2}}{I} d s \cong \frac{s}{3} \sum \frac{y^{2} K}{I}
$$

since

$$
\int f(x) d x \cong \frac{s}{3}\left(y_{0}+4 y_{1}+2 y_{2}+4 y_{3}+\cdots\right)
$$

so

$$
H=\frac{\int \frac{M y}{I} d s}{\int \frac{y^{2}}{I} d s}
$$

where the coefficients $1,2,4,=K$ values and $s=$ segmental length of the arch. Tedesko analyzed the two-hinged arch as 16 individual segments. Here, $s=18.83 \mathrm{ft}$ and he calculated $M$ at each point 0 through 8 , for the cases of rib weight, roof shell weight, snow load, wind load, and temperature variations. A summary of the calculations needed to obtain the horizontal thrust is presented in Table 2.

We will describe the first row of Table 2 in detail. The bending moment $M$ in Table 2 is not the final moment, it is the moment due only to vertical loads and the vertical reactions described in Eq. (6) and it is calculated as

$$
M=\sum(\text { seg weight } \times \text { arm })-R_{\text {vert }} \times L
$$

The segmental weights are easily calculated, which naturally leads to the vertical reaction $R_{\text {vert }}$. The values of interest are shown in the last two columns of Table 2 where $x$ is the horizontal distance between the centroid of each segment and the centerline of the arch. Here, $R_{\text {vert }}=403.6 \mathrm{k}$. The half-span value of $x$ is 110 $\mathrm{ft}$ thus

$$
\begin{aligned}
M & =26.02 \times 9.33+27.1 \times 28+29.25 \times 45.8+\cdots-403.6 \times 110 \\
& =11120 \mathrm{ftk}
\end{aligned}
$$

The Simpson's rule calculation uses the summations in the eighth and ninth columns of Table 2, then concludes with the $s / 3$ multiplications. Then, multiply by two to account for both halves

$$
\begin{aligned}
\int \frac{M y}{I} d s & =\left(\sum \frac{M y K}{I}\right) \frac{* s}{3} \times 2=213,636 \times \frac{18.83}{3} \times 2 \\
& =\frac{2,681,841 \mathrm{k}}{\mathrm{ft}^{2}}
\end{aligned}
$$

and

$$
\int \frac{y y}{I} d s=\left(\sum \frac{y y K}{I}\right) \times \frac{s}{3} \times 2=1,608 \times \frac{18.83}{3} \times 2=\frac{20,180}{\mathrm{ft}^{2}}
$$

Finally,

$$
H=\frac{\int \frac{M y}{I} d s}{\int \frac{y^{2}}{I} d s}=\frac{2,681,841}{20,180}=133 \mathrm{k}
$$

Tedesko's calculations give the same result.

Obviously, once the horizontal thrust is known, the arch rib 
Table 3. Reactions and Moments in Two-Hinged Arch-Rib

\begin{tabular}{|c|c|c|c|c|c|c|}
\hline \multirow[b]{4}{*}{ Point } & \multirow{2}{*}{\multicolumn{2}{|c|}{$\begin{array}{l}\text { Weight of rib alone } \\
H_{\mathrm{Ted}}=133.0 \mathrm{kips}\end{array}$}} & \multicolumn{2}{|c|}{ Weight of rib, vault, and snow } & \multicolumn{2}{|c|}{ Effect of temperature drop $80--25 \mathrm{~F}$} \\
\hline & & & & & \multicolumn{2}{|c|}{$H_{\mathrm{Ted}}=2.8 \mathrm{kips}$} \\
\hline & \multicolumn{2}{|c|}{$H_{S A P}=135.7 \mathrm{kips}$} & \multicolumn{2}{|c|}{$H_{S A P}=372.2 \mathrm{kips}$} & \multicolumn{2}{|c|}{$H_{S A P}=1.9 \mathrm{kips}$} \\
\hline & $\begin{array}{c}M_{T e d} \\
\text { (ft kips) }\end{array}$ & $\begin{array}{c}M_{S A P} \\
\text { (ft kips) }\end{array}$ & $\begin{array}{c}M_{\mathrm{Ted}} \\
\text { (ft kips) }\end{array}$ & $\begin{array}{c}M_{S A P} \\
\text { (ft kips) }\end{array}$ & $\begin{array}{c}M_{\text {Ted }} \\
\text { (ft kips) }\end{array}$ & $\begin{array}{c}M_{S A P} \\
\text { (ft kips) }\end{array}$ \\
\hline Crown 0 & 360 & 180 & 1760 & 915 & 225 & 150 \\
\hline 1 & 210 & 140 & 1461 & 698 & 222 & 147 \\
\hline 2 & 126 & 17 & 873 & 68 & 209 & 139 \\
\hline 3 & -225 & -173 & -432 & -849 & 189 & 126 \\
\hline 4 & -376 & -400 & -1469 & -1857 & 162 & 108 \\
\hline 5 & -865 & -809 & -3042 & -3214 & 130 & 87 \\
\hline 6 & -1774 & -1724 & -5564 & -5538 & 95.8 & 64 \\
\hline 7 & -1697 & -1777 & -4897 & -5224 & 52.2 & 35 \\
\hline Base 8 & 0 & 0 & 0 & 0 & 0 & 0 \\
\hline
\end{tabular}

becomes statically determinate and bending moments and shear forces can be easily found at any cut. We compare Tedesko's original hand calculations to results obtained from the commercially available program SAP2000 in Table 3. The arch rib was discretized into nonprismatic beam elements. The load cases studied by Tedesko were also programmed into SAP2000. Table 3 gives several examples of these results. For design, the differences in Table 3 are insignificant.

\section{Shell Analysis}

The $N_{\phi}^{\prime}$ compressive stresses in the shell are calculated by Tedesko at the crown (Point 0) and at subsequent successive cuts to the shell springing point (Point 6). Defining the $z$ axis as radial, we see the stress resultant

$$
N_{\phi}^{\prime}=-p_{z} \times r
$$

where $r=$ radius of the barrel shell (here $125.15 \mathrm{ft}$ ) and $p_{z}=$ pressure along $z$. For a uniform shell dead load $p_{d}$, the loading component along $z$ is

$$
p_{z}=p_{d} \times \cos \left(\phi_{k}-\phi\right)
$$

Here, the load $p_{d}$ is comprised of shell weight, roofing materials, and snow load, for a total of $73 \mathrm{lb} / \mathrm{ft}^{2}$.

At the crown the angle is zero $\left(\phi_{k}=\phi\right)$ thus,

$$
N_{\phi}^{\prime}=73 \mathrm{lb} / \mathrm{ft}^{2} \times 125.15 \mathrm{ft} \times \cos (0)=9.1 \mathrm{k} / \mathrm{ft}
$$

The stress in the shell at the crown is then (see Table 4)

$$
\frac{N_{\phi}^{\prime}}{h}=\frac{9.1 \mathrm{k} / \mathrm{ft}}{3.5 / 12 \mathrm{ft}}=31.2 \mathrm{k} / \mathrm{ft}^{2}
$$

The shell stresses can be obtained readily from SAP2000. Peak compressive stresses at the crown are $31.2 \mathrm{k} / \mathrm{ft}^{2}$. Since there is practically no bending stress at the crown, the finite-element solution agrees with the membrane hand calculation.

In this paper, we use the more standard notation where $T_{2}$ $=N_{\varphi}$ and $N_{\phi}^{\prime}$ implies membrane theory results. The $T_{2}$ forces must be equilibrated by the ribs as shown in Fig. 2, which was taken from Tedesko's calculations. At the crown, this equilibrating thrust in the ribs is tensile as shown in Fig. 2. Call this addi- tional thrust $N_{T 2}$. Furthermore, if the shell centerline is eccentric some distance $e$ to the rib centerline, then an additional moment $M_{T 2}$ will be induced.

The presence of the edge member affects the thrust in the $N_{\phi}$ direction, which is reduced before it reaches the lower edge. These "ring stresses" are carried to the arch ribs by a new set of longitudinal thrusts in the $N_{x}$ direction and shear forces $S$ instead of going directly down to the edge member (Molke and Kalinka 1938).

This flow of stresses will occur even with the presence of a very light edge beam. The edge of the shell essentially acts as a flat diaphragm when subjected to an in-plane uniform load, as noted by Molke and Kalinka (see Fig. 3). Our finite-element results verify this flow of stresses, and allow us to investigate the stresses near the arch ribs in greater detail. We found that the $N_{x}$ direction stresses are practically constant across the crown of the shell, with a magnitude of $12 \mathrm{k} / \mathrm{ft}^{2}$. The in-plane shear stresses $N_{x \phi}$ are insignificant, on the order of $1 \mathrm{k} / \mathrm{ft}^{2}$.

Tedesko predicted that the $N_{\phi}$ direction (ring) stresses would remain constant longitudinally, except for a short distance from the arches where a portion of the shell contributes to the arch like the slab flange to a $\mathrm{T}$ beam. Near the arch ribs, shell action disappears. Furthermore, Tedesko calculated that the $N_{\phi}$ direction stresses would have the largest compressive magnitude at the crown, and would dissipate moving towards the springing line. He stated that the $N_{\phi}$ direction stresses would be slightly tensile at the springing line where the horizontal edge beam meets the shell, which would mean that the "flat side-roof hangs from the shell" (Tedesko 1936). Our finite-element analysis shows a slight tensile stress Point 6, due to the hanging of the edge beam off of

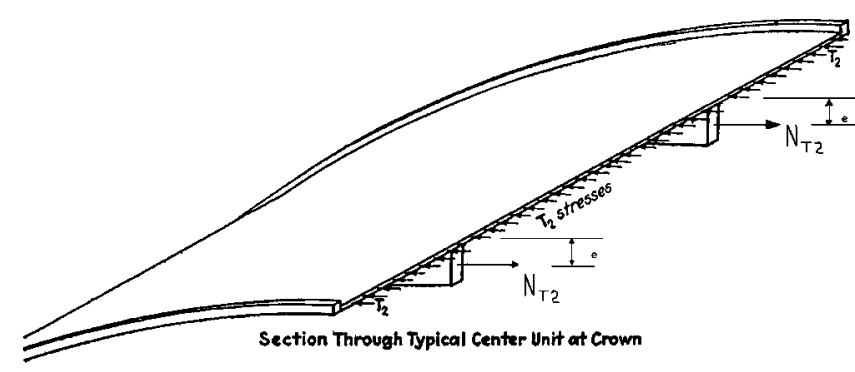

Fig. 2. Description of $T_{2}$ and $N_{T 2}$ and $M_{T 2}=N_{T 2} \times e$ 
Table 4. Summary of Ring Stresses in Shell due to DL+LL

\begin{tabular}{lcc}
\hline & $\begin{array}{c}\text { Tedesko } \\
N_{\phi}^{\prime} / h \\
\left(\mathrm{k} / \mathrm{ft}^{2}\right)\end{array}$ & $\begin{array}{c}\text { SAP } \\
N_{\phi} / h \\
\left(\mathrm{k} / \mathrm{ft}^{2}\right)\end{array}$ \\
\hline Point & -31.2 & -31.8 \\
1 & -30.7 & -31.6 \\
2 & -28.9 & -33.5 \\
3 & -27.0 & -33.0 \\
4 & -16.7 & -27.3 \\
5 & -13.7 & -5.9 \\
6 & -3.6 & 5.6 \\
\hline
\end{tabular}

the shell, and virtually no variation of the $N_{\phi}$ direction stresses spanning across the shell from rib to rib. There is almost no bending at the crown, but bending is exhibited elsewhere, particularly lower than Cut 4. These axial stresses are shown in Table 4.

\section{Analysis of Combined Arch-Rib and Shell}

The prior two analyses conducted by Tedesko (two-hinged arch rib, shell as membrane) are approximations of the real situation. Tedesko understood very well how the forces flowed in these thin shell structures and he made the following superposition to analyze the final forces and moments. He knew that the arches do not act alone, nor does the shell carry all of the roof load alone. Rather, the shell at the crown carries nearly all the roof load not to the arch, but down the curved shell itself in the $N_{\phi}$ direction. Such action was also predicted by Molke and Kalinka as shown in Fig. 3, where compression trajectories near the crown are nearly aligned with the $N_{\phi}$ direction. This action would induce an equilibrating tensile force and bending moment as shown in Fig. 2. Moving down the shell from the crown, the forces flow more towards the supporting arch rib. Near the springing point, Cut 6 , the presence of the edge beam induces tension forces which are orthogonal to the compression forces shown in Fig. 3. Table 5 summarizes the equilibrating forces at the crown (Cut 0) and at Cut 6. Note that at Cut 6 , the eccentricity $e$ is 0 , inducing no equilibrating bending moment Fig. 4.

We can check the adequacy of the reinforcement of the arch rib at Cut 6, since this is the cross section subjected to the most severe bending moment. The rectangular rib cross section has a depth here of $14.4 \mathrm{ft}$ and a width of $1.83 \mathrm{ft}$. There are 5 in. of cover to the top steel and 3 in. of cover to the bottom steel. The design moments are not those reported in Table 5 but are similarly calculated by us as an arch rib not as an arch shell. The design

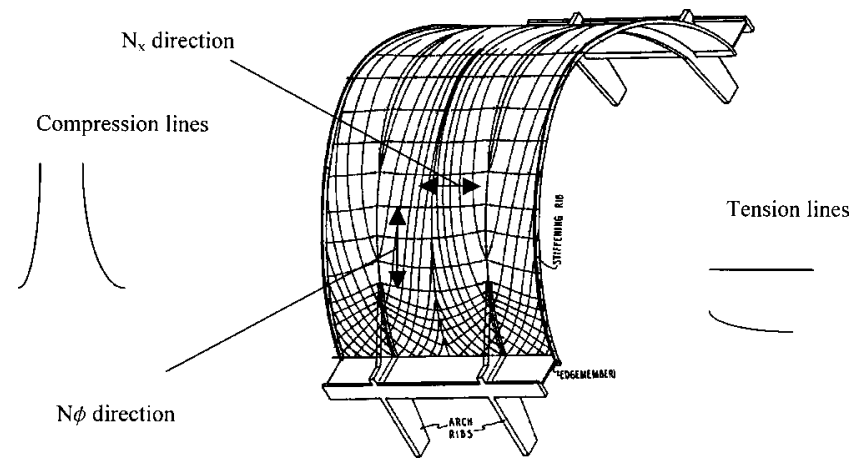

Fig. 3. Molke and Kalinka's analysis of Hershey

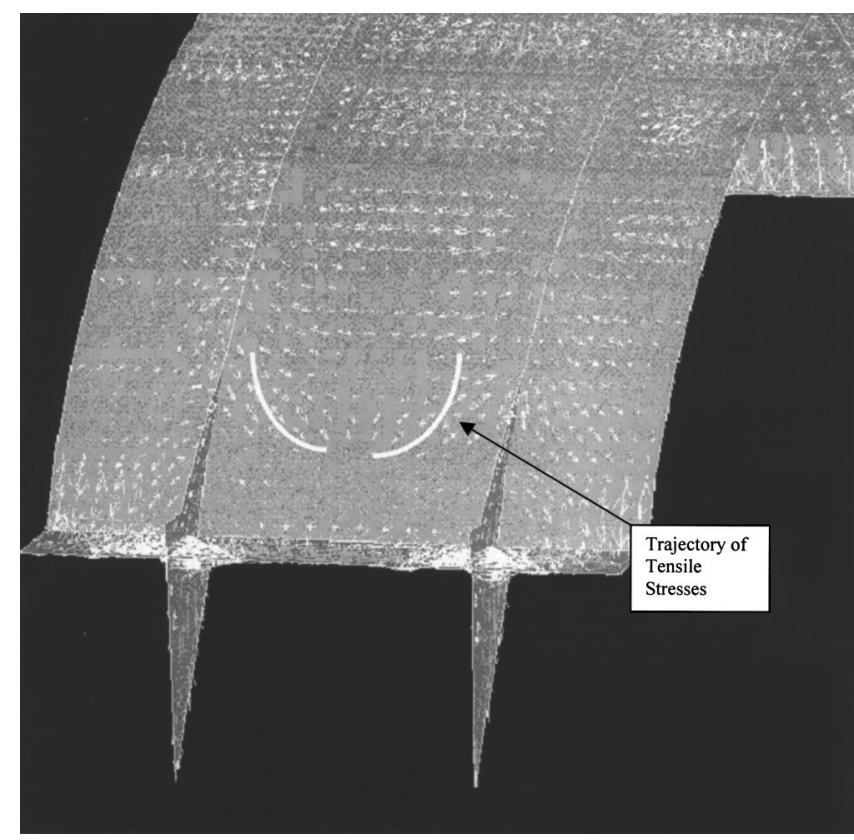

Fig. 4. Plot of principal stress

moments take into account combinations of wind, temperature, water on one side, as well as dead load and live load. Thus, the design moment was $-6,488 \mathrm{ft} \mathrm{k}$ and the design normal force was $-575 \mathrm{k}$. Tedesko designed the cross section at Cut 6 to have 15.2 in. $^{2}$ at the top of the section and he calculated that no steel is needed at the bottom of this section. We can check the adequacy of this design by use of the following working stress equations:

$$
\begin{gathered}
M=\frac{1}{2} f_{c} k h b\left(\frac{h}{2}-\frac{k h}{3}\right)+A_{s} f_{s}(d-k h) \\
N=\frac{1}{2} f_{c} k h b-f_{s} A_{s}
\end{gathered}
$$

where $f_{c}=$ working stress in the concrete, which is compared to $f_{c}^{\prime}=3,000 \mathrm{lb} /$ in. $^{2}$ and $f_{s}=$ working stress in the steel, which is compared to $f_{\text {smax }}=22,760 \mathrm{lb} /$ in. $^{2} ; \quad b=22 \mathrm{in}$.; $d=168 \mathrm{in}$; and $k=$ dimensionless factor.

Solving Eqs. (20) and (21) for $k, f_{c}$, and $f_{s}$ which result in the design $M$ and $N$ values, we find

$$
k=0.413, \quad f_{c}=1,066 \mathrm{lb} / \text { in. }^{2}, \quad \text { and } f_{s}=17,284 \mathrm{lb} / \mathrm{in}^{2}
$$

This shows that the steel choice is adequate and conservative.

Fig. 5 shows output from a second finite-element analysis, this time using the commercially available program ANSYS. The advantage of this program is that it readily shows trajectories of principal stresses. Note in Fig. 5 that the principal stresses flow in a fashion very similar to that predicted by Molke and Kalinka. The direction of these stresses is important, because Tedesko laid out the reinforcing bars along the principal tensile stress trajectories. Tedesko points out (Tedesko 1937b) that the flow of stresses near the edge beam demonstrates that the shell structure acts differently than an arch would. One would expect compression due to thrust at the springing line, not a tensile force. The fact that the shell hangs between the supporting arch frames necessitated placing the reinforcing bars in a pattern "suggestive of the shape of 
Table 5. Equilibrating Bending Moment Corrections

\begin{tabular}{|c|c|c|c|c|c|}
\hline Cut & $e$ & $M_{T 2}$ & $\begin{array}{l}\text { Arch rib } \\
\text { alone } \\
M_{\mathrm{DL}+\mathrm{LL}}\end{array}$ & $\begin{array}{c}\text { Final with } T_{2} \\
\text { correction } \\
M_{\mathrm{DL}+\mathrm{LL}}\end{array}$ & $\begin{array}{c}\text { Final } \\
S A P \\
M_{\mathrm{DL}+\mathrm{LL}}\end{array}$ \\
\hline & $\mathrm{ft}$ & $\mathrm{ft} \mathrm{k}$ & $\mathrm{ft} \mathrm{k}$ & $\mathrm{ft} \mathrm{k}$ & $\mathrm{ft} \mathrm{k}$ \\
\hline 0 & 2.07 & -574 & 1,760 & 1,186 & 737 \\
\hline 6 & 0 & 0 & $-5,564$ & $-5,564(e=0)$ & $-6,003$ \\
\hline
\end{tabular}

cables of a suspension bridge" (Tedesko 1937b). All tensile stresses (the white arcs in Fig. 4) are resisted by steel reinforcement.

\section{Construction of the Shell}

Tedesko realized that the Hershey project would be like no other. He referred to it as a "home-made structure, constructed by Hershey men" (Tedesko 1978). The naiveté of the Hershey personnel became immediately apparent to Tedesko, who took it upon himself to be planner/architect/engineer/construction manager. Mr. Hershey wanted to save money and refused to formally hire a construction manager. The result was a rather chaotic beginning to the erection process, since Hershey personnel tried to insert architectural details, as well as hinder the path of construction progress. Eventually, Tedesko secured the help of Oscar Spancake, a carpenter-foreman, who mobilized a crew of 250 men, 4 concrete mixers, and 2 elevators. The workers had no previous experience in concrete construction, leaving Tedesko no choice but to supervise all aspects of the concrete pours. Remarkably, by July 2, 1936 the first roof pouring operations began.

Formwork for the huge arch ribs was made up of a patchwork of standard lumber sizes, secured by Witmer, since Mr. Hershey stipulated that all the lumber associated with the project later be used in the construction of barns and homes in Hershey. In July of 1936, Witmer and Spancake struggled mightily with the concrete mixture, since Tedesko stipulated that the pours be done starting on the ground level on both sides, with continuous pouring until the two pours came together at the top of the arena (Rotary Club of Hershey 1992). These pours took anywhere from 14 to 20 days, working $24 \mathrm{~h}$ a day. The concrete was mixed in a batch plant on the site. Tedesko called for concrete in the shell to have a 1 in. slump, but concrete used for the arch rib at the ground

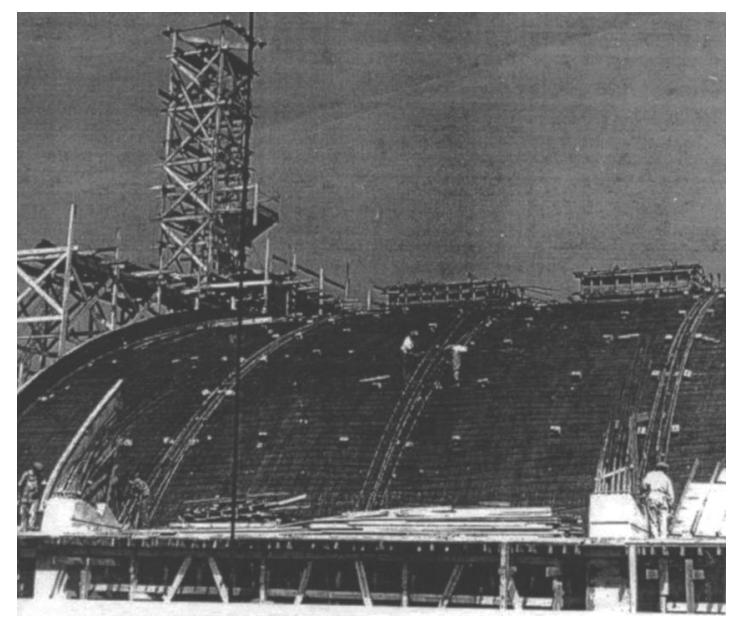

Fig. 5. Reinforcing steel of arch ribs

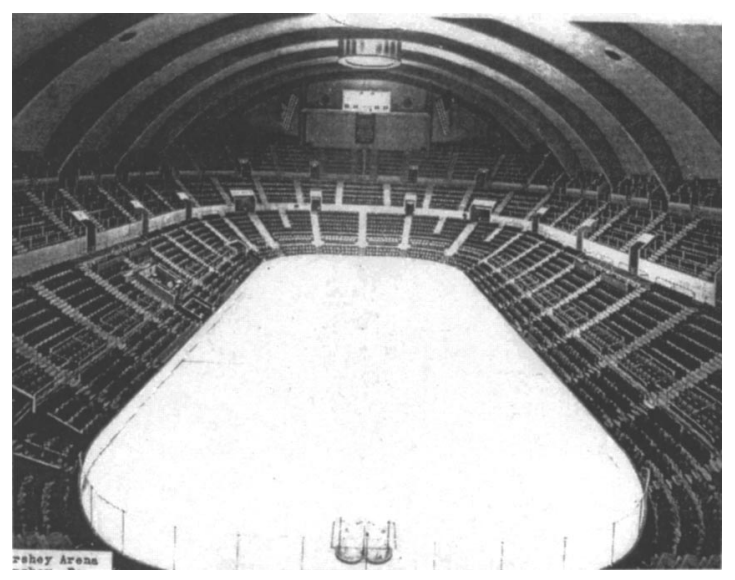

Fig. 6. Interior of completed Ice Arena

floor needed a 6 in. slump because of the intricate reinforcing at the springing point. Two mixers were placed on each side of the arena, to make two different workabilities of concrete, then buggies were used to wheel the concrete from the mixer to the formwork. Different colored tags were put on the buggies to identify the slump (Witmer 1937).

The scaffolding structure was built of yellow pine lumber, and the entire scaffolding and formwork structure rested on a series of 250 jacks (Hershey Sports Arena 1936). Once the pours were complete, the forms were lowered slightly so that the concrete could begin to carry its own weight. After a minimum period of curing, the jacks would then be lowered (Rotary Club of Hershey 1992), and the forms would drop away from the concrete shell. Witmer reported that the normal concrete deflection was about 2 $1 / 2$ in. and when they lowered the first form, the concrete continued to stay attached to the forms for the first 2 in. He was sure that a monumental failure was about to occur. Eventually, the concrete stopped settling as the forms were lowered further.

\section{The Old and The New}

The historical significance of the Hershey Ice Arena is unquestionable. At the time of completion (see Fig. 6), it was the largest thin shell concrete structure in North America. The success of this structural form has been established in American history, as witnessed by the large number of arenas and airplane hangars modeled after the Hershey Ice Arena. The Arena has continuously been used over the past 60 years to house sporting competitions, as well as musical and theater events, and is still in excellent condition today. This structure is a testament both to the brilliance of its designer Tedesko, as well as to the remarkable vision of its original owner, Mr. Hershey.

However, the Governor of Pennsylvania has only recently appropriated \$25 million dollars towards the construction of a new $\$ 75$ million arena, to be located near the original structure. Promises have been made that the original arena "will remain a community resource," but in light of the recent destruction of the Kingdome, efforts must be made to secure the safety of Tedesko's and Hershey's monolithic masterpiece. To this end, we are pursuing ASCE and National Landmark Status for the Hershey Ice Arena, with the hope of preserving a unique piece of our cultural heritage. 


\section{Acknowledgments}

The writers gratefully acknowledge that partial support for this work was provided by the National Science Foundation, Award No. 0095010 to Princeton University. Thanks are also given to Pam Whitenack of the Hershey Community Archives for her able assistance.

\section{References}

Alexander, W. H., Rotary Club of Hershey. (1992). “The Builder, D. Paul Witmer." Transcript of presentation to Club, November 23, 1992.

American Society of Civil Engineers (ASCE). (1952). "Manuals of engineering practice, No. 31." Design of concrete shell roofs, New York.

Billington, D. P. (1982a). "Anton Tedesko: Thin shells and esthetics." $J$. Struct. Div., ASCE, 108(ST11), 2539-2554.

Billington, D. P. (1982b). Thin shell concrete structures, 2nd Ed., McGraw-Hill, New York, 16.

Cassidy, P., and Harrison, E. (1988). One man's vision: Hershey, a model town, Hershey, Pa.

Dyckerhoff and Widmann A. G. (1931). "Schalengewolbe System
»Zeiss-Dywidag«." Promotional brochure, Wiesbaden-Berlin, Princeton Univ. Maillart Archives.

Flugge, W. (1934). Statics and dynamics of shells, Springer, Berlin.

Hayden Planetarium. (1935). Engineering News Record, July 25, 1935 , 105 and Jan. 2, 23.

Hershey Community Archives. (1954). Accession 97004, B2, F37; Paul A. Wallace interview with Chance Phillips.

Hershey Community Archives. (1989). Oral history collection, interviews with Richard A. Bacastow (90OH11), George Booth (89OH06).

Hershey Sports Arena Program. (1936). "Hershey sports arena finest rink in America."

Molke, E. C., and Kalinka, J. E. (1938). "Principles of concrete shell dome design." Proc., American Concrete Institute, 34, 649-706.

Snavely, J. R. (1957). Ar intimate story of M. S. Hershey, Hershey, Pa

Tedesko, A. (1936). "Structural design analysis Hershey Park Arena." Design Documentation, Princeton Univ. Maillart Archives, 76.

Tedesko, A. (1937a). "Large concrete shell roof covers ice arena." Eng. News-Rec., April 8, 505-510.

Tedesko, A. (1937b). "Z-D shell roof at Hershey." Arch. Conc., 3, 7-11.

Tedesko, A. (1978). "Autobiography." Maillart Archives, Princeton Univ. Princeton, N.J.

Von, Mises (1914). Z. Ver. deut. Ingr., 58, 750.

Witmer, D. P. (1937). "Sports palace for a chocolate town." Arch. Conc., 3(1), 3-6. 